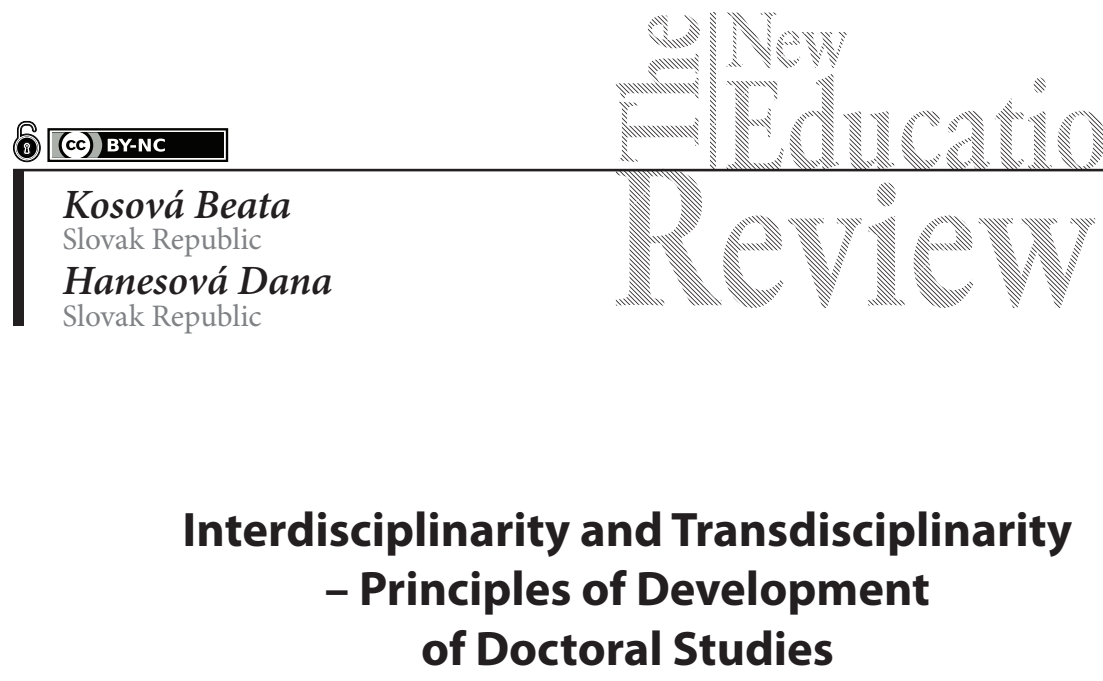

DOI: 10.15804/tner.2020.61.3.02

\begin{abstract}
:
In future, changes in science and society will increasingly demand interdisciplinarily prepared professionals and researchers. Inter/transdisciplinarity has been worked on theoretically and scientifically examined. This review study shows how both approaches are explained, how they are put into practice in doctoral studies, the results of the interdisciplinary approaches applied, but also their limitations and barriers.
\end{abstract}

Key words: interdisciplinarity, transdisciplinarity, doctoral studies.

\title{
Introduction
}

At the turn of the $21^{\text {st }}$ century there are fundamental changes in the concept of science and in the way of knowledge is produced. According to Gibbons et al. (1994), science passes from Mode 1 to Mode 2, from a monodisciplinary conception to changeable and purposeful research fields where the goal is mainly to effectively influence reality. In this Mode, science has an inter/transdisciplinary and heterogeneous character; theory and practice as well as basic and applied research intertwine, creating the so-called hybrid science with a large amount of knowledge produced in the context of application. Science should introduce innovations at a rapid pace, which requires academics to take part in various 
inter-disciplinary discourses and interactions. Scientific communities re-group to form temporary networks with various actors in relation to the problems needing to be dealt with. Research is typical of organizational diversity, diversity of research strategies and environments.

In the $2^{\text {nd }}$ decade of the $21^{\text {st }}$ century, new requirements for the future of professions are already clearly articulated. This is apparent from the extensive survey conducted by the World Economic Forum (WEF, 2016, 2018). By 2022, in a quarter of today's job positions, it is expected that more than $70 \%$ of work tasks will have been automated on the basis of collaboration between humans and technology (WEF, 2018, pp. 10-11). The report warns that the system of acquisition of traditional qualifications, which is focused on "hard" professional competencies, preparing ready-made specialists for a single field, is already obsolete and is hindering future progress. More than specialists, persons capable of solving a certain area of problems, able to take into account all that is related as well as arising contexts will be wanted (WEF, 2016, p. 32). Inter-disciplinarily prepared employees are required, with emphasis placed not on their factual knowledge, because data and theories will be "delivered" mainly by machines, but substantially on transversal skills, which will become the core of most occupations (ibid., p. 22).

Changes in the concept of science and professions also require a new style of academic thinking beyond disciplinary "boxes". One effective way is seen in the training of new academics. New models are emerging of doctoral studies, e. g. a professional or collaborative doctorate, based on inter- and trans-disciplinary collaboration (Louw \& Muller, 2014, Borell-Damian, 2015). 85\% of European universities in the European University Association (EUA) have doctoral schools or similar specific structures for doctoral education (Hasgall et al., 2019, p.8) aimed at development of transversal skills, inter- and trans-disciplinarity by a panel of supervisors from various disciplines. According to Darbellay, (2015) "in the light of an academic organization" inter- and trans-disciplinarity might be viewed as a disruptive innovation strategy or as a means of evolutionary transformation of universities. In this digital context, the medium and long-term sustainability of our universities will depend on their capacity for innovation between and beyond disciplinary divides based on dual logic of continuity and transformation (pp. 172-173).

\section{Methods of research}

To elucidate this further, a narrative review study has been chosen, which describes the findings obtained by previous research, summarizes them, reaches 
more general conclusions and may provide a form of explanation of various aspects of the problem (Mareš, 2013, p. 430). The form of a narrative review study has been preferred for two reasons. The first being the fact that there are a very large number of publications and studies in the world literature, written prevailingly in English, about inter- and trans-disciplinarity and about doctoral studies, that cannot be treated within the scope of this contribution. A narrative review study allows us to concentrate on only a representative sample of works, or to carry out a targeted overview structured by selected aspects. The second reason is that in Central European countries, this issue has not yet received sufficient attention. Contributions by authors from these countries are rare, and do not address the concept of inter-disciplinarity either in general, or in relation to doctoral studies. ${ }^{1}$ In the Central European area, this is therefore a mapping of the state-of-the-art, summarization of research results and integration of the findings without claiming complexity in order to give the reader an introductory and at least partially conceptual an insight.

The review has been created to answer three research questions: 1) How is inter/ trans-disciplinarity defined theoretically? 2) How is inter/trans-disciplinarity promoted in doctoral studies? 3) What are the research results of the impact of inter-disciplinarity on students (especially) of doctoral studies?

Phase 1 was a world databases review ${ }^{2}$ of literature published after the year 2000, using the key words "interdisciplinary", "transdisciplinary" and "doctoral studies". Due to the fact that only periodicals directly dealing with doctoral studies provided more than 2000 sources, it was necessary to narrow down the selection in a targeted manner. In Phase 2, which lasted almost one year, more key terms were gradually searched for and reviewed. To establish conceptual definitions, the substantives inter-disciplinarity and trans-disciplinarity were worked with. For inter-disciplinary activities in Ph.D. studies, the terms interdisciplinary doctoral studies/instruction/training, interdisciplinary teaching strategies, but after studying various aspects of the problem, the terms doctoral/graduate/postgraduate school were also used. The existence of interdisciplinary activities was reviewed on websites of 15 universities and their doctoral schools in 14 EU countries. To find out results on research, the term interdisciplinary research was also used in addition to

1 Between 2005 and 2019, the Central European periodical The New Educational Review published 8 contributions with the key word "interdisciplinary", but addressing an interdisciplinary approach to counseling, rehabilitation, visions of university, definitions of training or integration of information in instruction in selected subjects.

2 The co-author of the study conducted the literature search during her short visit to Cambridge University in 2018 in the databases the University had access to. 
the terms above. It is not possible to express numerically how many abstracts were studied in Phase 2. Phase 3 - production of reviews and synthesizing conclusions - included 64 publications and studies ${ }^{3}$ published from 2005 to 2018 in English and relating to the 3 research questions above.

\section{Results}

\section{Theoretical definition of inter-disciplinarity and trans-disciplinarity}

The theoretical definition of inter/trans-disciplinarity is based on 11 representative sources. According to most of them, inter-disciplinarity is more than juxtaposing different disciplinary viewpoints, because it involves collaborative and integrative approaches by disciplines to a given topic of research. First it was characterized as bringing together distinctive components of two or more disciplines (Nisani, 1997, p. 203). At present it is defined as collaboration of established disciplines that interact dynamically to allow the complexity of a given object to be studied (Darbellay, 2015, p. 165). It is interaction between different bodies of knowledge or research practices, a variety of different ways of bridging and confronting the prevailing disciplinary approaches, including all activities that juxtapose, apply, combine, synthesize, integrate or transcend parts of two or more disciplines (Huutoniemi et al., 2010, p. 80). It can be a matter of transferring or borrowing concepts or methods from another scientific field, or of hybridization, or transferring mechanisms between disciplines, at an empirical, methodological or complex theoretical level, thus from integration of data and methods to a new field of knowledge, or a new paradigm of approach (ibid., p. 82-85).

The aim of interdisciplinary effort is to overcome the conceptual and methodological boundaries between fields of research in order to acquire new knowledge. Therefore, in addition to the aspect of interaction the aspect of production is also emphasized - the creation of knowledge, and research that transcends disciplinary boundaries, deals with problems by interconnecting several points of view, and rejecting solutions from single disciplines (Hicks et al., 2010, Bridle et al., 2013, Darbellay, 2015). A new field of research is created that cannot be assigned

${ }^{3}$ For all sources and web sites of universities see: Kosová, B., Hanesová D., Šukolová, D. et al., 2019, https://www.pdf.umb.sk/katedry/katedra-elementarnej-a-predskolskej-pedagogiky/ publikacie/book-19337/doktorandska-skola-cesta-k-transformacii-a-inovacii-doktorandskeho-vzdelavania-vo-svete-a-na-slovensku.html 
to any particular scientific discipline (e. g. transformation of society, migration, diversity, etc.).

Trans-disciplinarity of research and education is based on the fact that today knowledge is not born only on the border between scientific disciplines, but is increasingly circulating between theory and practice. According to Darbellay (2015, p. 166) this trend has two major and complementary orientations:

- Epistemological/theoretical trans-disciplinarity - This is a process of knowing that transcends boundaries not only between sciences but also all components of reality; it entails reconfiguring disciplinary divisions within a global and integrated perspective;

- Pragmatic/applied trans-disciplinarity - This is a method of research that brings political, social, and economic actors, as well as ordinary citizens, into the research process itself in a "problem-solving perspective", from outside contributing to the construction of knowledge and solution of social problems (see Bridle et al., 2013).

Current research requires "the transdisciplinary combination of knowledge resources beyond the boundaries of an academic context" (Huutoniemi et al., 2010, p. 80). Applications and innovations in the transdisciplinary mode include universities, service institutions, businesses, the third sector, etc. Researchers get impulses from various work teams, professional associations and employers, with research transforming its conclusions to innovations which meet their needs.

\section{Introducing inter-disciplinarity and trans-disciplinarity to doctoral studies}

Universities have developed a variety of activities in the area of inter-disciplinarity (supplemented by a transdisciplinary dimension, as the case may be) that are gradually changing the character of research and the training of beginning researchers. Table 1 presents authors treating the issue theoretically or gives examples of universities implementing the issue in practice.

Apart from a variety of activities, interdisciplinary teaching strategies are a common way in which development of inter-disciplinarity is defined and which allows different perspectives to be seen. The core of this is seen in interdisciplinary encounters where professionals from various disciplines discuss and work together "face to face" and this has the aim of fostering interdisciplinary thinking and collaboration (Bridle et al., p. 23). The purpose is to achieve open communication, which implies listening to, being curious about, and understanding each other's perspectives and the potential contributions of each discipline to joint efforts. This communicative attitude is referred to as appreciative inquiry (Graybill, 2006, 
Table 1. Main ways of development of inter-disciplinarity in Ph.D. studies

\begin{tabular}{|c|c|c|}
\hline \multirow{3}{*}{$\begin{array}{l}\text { Exposure to } \\
\text { inter-disciplinarity } \\
\text { in the study of the } \\
\text { discipline }\end{array}$} & $\begin{array}{l}\text { Obligation to choose a course in another } \\
\text { discipline }\end{array}$ & University of Szeged \\
\hline & Interdisciplinary courses & $\begin{array}{l}\text { University of Helsinki } \\
\text { London Global University, etc. }\end{array}$ \\
\hline & The second supervisor from another discipline & $\begin{array}{l}\text { Institute of Science and Technology, } \\
\text { Austria }\end{array}$ \\
\hline \multirow[t]{4}{*}{$\begin{array}{l}\text { Interdisciplinary } \\
\text { doctoral studies }\end{array}$} & Interdisciplinary theme of the dissertation & $\begin{array}{l}\text { Jones, } 2010 \\
\text { Institute of Science and Technology, } \\
\text { Austria } \\
\text { Open University, UK }\end{array}$ \\
\hline & $\begin{array}{l}\text { Interdisciplinary curriculum taught by various } \\
\text { experts }\end{array}$ & $\begin{array}{l}\text { Jones, } 2010 \\
\text { University of Helsinki } \\
\text { University of Leicester, } \\
\text { London Global University }\end{array}$ \\
\hline & Interdisciplinary teaching strategies & $\begin{array}{l}\text { Bridle et al., } 2013 \\
\text { Graybill et al., } 2006 \\
\text { Duerr, } 2008\end{array}$ \\
\hline & Team/panel of supervisors, team-teaching & $\begin{array}{l}\text { Carr et al., } 2018 \\
\text { Taylor et al., } 2018 \\
\text { Jones, } 2010 \\
\end{array}$ \\
\hline \multirow[t]{3}{*}{$\begin{array}{l}\text { Transdisciplinary } \\
\text { doctoral studies }\end{array}$} & Collaborative doctorate & $\begin{array}{l}\text { Borrell-Damian et al., } 2015 \\
\text { Taylor et al., } 2018\end{array}$ \\
\hline & Professional doctorate & Louw \& Muller, 2014 \\
\hline & Inter-institutional networking & $\begin{array}{l}\text { London Global University } \\
\text { Central European Institute of Tech- } \\
\text { nology }\end{array}$ \\
\hline \multirow[t]{7}{*}{$\begin{array}{l}\text { Doctoral schools for } \\
\text { doctoral students of } \\
\text { various disciplines }\end{array}$} & $\begin{array}{l}\text { Interdisciplinary structure } \\
\text { (university, supra-disciplinary structure, con- } \\
\text { sortium of universities, etc.) }\end{array}$ & $\begin{array}{l}\text { Matas, } 2012 \\
\text { University of Edinburgh } \\
\text { Université Pierre-et-Marie-Curie, } \\
\text { Paris } \\
\text { University of Utrecht. }\end{array}$ \\
\hline & Joint education & Hasgall et al., 2019 \\
\hline & Joint research & Carr et al., 2018 \\
\hline & Joint work (projects, products, co-authorship) & $\begin{array}{l}\text { Bridle et al., } 2013 \\
\text { Saari \& Moilanen, } 2012\end{array}$ \\
\hline & Joint events, presentations, evaluations & $\begin{array}{l}\text { Carr et al., } 2018 \\
\text { Saari \& Moilanen, } 2012 \\
\text { All universities under review } \\
\end{array}$ \\
\hline & Joint training in transversal skills & $\begin{array}{l}\text { Hasgall et al., } 2019 \\
\text { All universities under review }\end{array}$ \\
\hline & Interdisciplinary encounters & $\begin{array}{l}\text { Bridle et al., } 2013 \\
\text { Graybill at al., } 2006 \\
\end{array}$ \\
\hline $\begin{array}{l}\text { Organizational } \\
\text { measures }\end{array}$ & Shared offices & Carr et al., 2018 \\
\hline
\end{tabular}

Source: own work 
p. 762). When people come from different mono-disciplinary backgrounds where terms and concepts have different meanings, it is important to carefully examine what is meant through clarification questions and formulation of conclusions.

Interdisciplinary encounters are a frequent form of work in doctoral schools of a cross-disciplinary character. They may include informal group discussions based on readings, fictional scenarios, lectures with discussions, presentations from participants with discussions, experience sharing, generating concrete outputs, e.g. a joint research proposal, position, formulation of a concept, project, article, video, or solution of an actual problem in practice. For encounters to fulfil their purpose of doctoral student education, according to Briddle et al. (2013, pp. 26-29) they require the facilitating leadership of someone who is capable of assuming the role of a mediator, so as to maintain focus, maximize creativity, develop confidence and self-confidence, build in frequent reflection moments, and foster appreciative inquiry.

The prevailing form of building doctoral students' inter-disciplinarity is setting up supra-disciplinary institutions and structures for the education of beginning researchers - university, supra-faculty, or thematic doctoral schools. These bring together doctoral students of various disciplines with the aim of producing a critical mass for research with sufficient diversity. There is a desire to de-privatize doctoral studies from the Humboldtian "master - apprentice" model to a model with the broad support of doctoral students from a team of supervisors from various disciplines, in order to develop transversal competencies.

\section{Research on inter- and trans-disciplinarity in doctoral studies}

Inter-disciplinarity itself has become a strong interdisciplinary research theme, with a number of research or evaluation reports by universities examining the benefits of exposing doctoral students' to inter-disciplinarity.

Carr et al. analyzed research to find conditions needed for the development of interdisciplinary collaboration. This prospered if researchers acknowledged and analyzed differences between disciplines, recognized limitations to their own mono-disciplinary approach, if they were able to communicate their research in a way that people from other disciplines understood it, if they were disposed to discuss and re-explain their approach until all involved in the discussion understood it, if they managed potential sources of conflicts arising from different ideas and minimized obstacles to constructive collaboration, and if they were disposed to negotiate compromises to reach a consensus. Regular face to face interaction, mutual trust, and a central figure who facilitated connectivity and collaboration between researchers appeared effective, too (Carr et al., 2018, 
Table 2. Benefits of the interdisciplinary approach for students

\begin{tabular}{|c|c|c|}
\hline \multirow[t]{8}{*}{$\begin{array}{l}\text { Cognitive development and } \\
\text { learning }\end{array}$} & $\begin{array}{l}\text { Critical thinking and independ- } \\
\text { ence }\end{array}$ & $\begin{array}{l}\text { Duerr, } 2008 \\
\text { Open University, UK }\end{array}$ \\
\hline & $\begin{array}{l}\text { Analysis of a theme from other } \\
\text { points of views, ability to ask inno- } \\
\text { vative questions }\end{array}$ & $\begin{array}{l}\text { Bridle et al., } 2013 \\
\text { Darbellay, } 2015\end{array}$ \\
\hline & $\begin{array}{l}\text { Synthesis of thoughts from many } \\
\text { perspectives }\end{array}$ & $\begin{array}{l}\text { Duerr, } 2008 \\
\text { Open University, UK }\end{array}$ \\
\hline & Creativity and flexibility & $\begin{array}{l}\text { Nissani, } 1997 \\
\text { Open University, UK }\end{array}$ \\
\hline & $\begin{array}{l}\text { Meaningful, authentic, purposeful, } \\
\text { deeper and life-long learning }\end{array}$ & $\begin{array}{l}\text { Duerr, } 2008 \\
\text { Open University, UK }\end{array}$ \\
\hline & $\begin{array}{l}\text { More original knowledge, under- } \\
\text { standing of relationships between } \\
\text { areas }\end{array}$ & $\begin{array}{l}\text { Castán Broto et al., } 2009 \\
\text { Nisani, } 1997 \\
\text { Duerr, } 2008 \\
\text { Carr et al., } 2018\end{array}$ \\
\hline & $\begin{array}{l}\text { Connection with real-world } \\
\text { contexts }\end{array}$ & Duerr, 2008 \\
\hline & $\begin{array}{l}\text { More intense educational experi- } \\
\text { ence, higher motivation }\end{array}$ & $\begin{array}{l}\text { Jones, } 2010 \\
\text { Open University, UK }\end{array}$ \\
\hline \multirow[t]{5}{*}{$\begin{array}{l}\text { Development of transferable } \\
\text { and social skills }\end{array}$} & $\begin{array}{l}\text { Ability to work in a team, toler- } \\
\text { ance, communication skills }\end{array}$ & $\begin{array}{l}\text { Jones, } 2010 \\
\text { Carr et al., } 2018 \\
\text { University of Helsinki } \\
\text { Institute of Science and } \\
\text { Technology, Austria }\end{array}$ \\
\hline & $\begin{array}{l}\text { Understanding people, abilities to } \\
\text { look at situations from their points } \\
\text { of view }\end{array}$ & $\begin{array}{l}\text { Duerr, } 2008 \\
\text { Jones, } 2010 \\
\text { Graybill et al., } 2006\end{array}$ \\
\hline & Self-confidence & Duerr, 2008 \\
\hline & $\begin{array}{l}\text { Understanding of the broader } \\
\text { impact of one's own area of knowl- } \\
\text { edge on society }\end{array}$ & Bridle et al., 2013 \\
\hline & $\begin{array}{l}\text { Ethos of respect for other disci- } \\
\text { plines }\end{array}$ & Castán Broto et al., 2009 \\
\hline \multirow[t]{2}{*}{$\begin{array}{l}\text { Practical advantages in the } \\
\text { career }\end{array}$} & $\begin{array}{l}\text { More available financing for re- } \\
\text { search on complex problems }\end{array}$ & Bridle et al., 2013 \\
\hline & $\begin{array}{l}\text { Increased potential for participa- } \\
\text { tion in research, identification of } \\
\text { a researcher in other disciplines }\end{array}$ & Bridle et al., 2013 \\
\hline
\end{tabular}

Source: own work 
pp. 37-38). According to evaluation by students of interdisciplinary doctoral studies, active participation in joint research, work and activities and joint supervision by supervisors from more disciplines were of the highest benefit. Shared offices, joint courses, social events and interdisciplinary study programmes were of some benefit. A neutral or low benefit was reported for seminars/lectures with experts from various fields (Carr et al., 2018, p. 44).

\section{Discussion}

Clearly the inter-disciplinarity and trans-disciplinarity of Ph.D. studies are developing rapidly in the world. However, there may be misconceptions in the understanding of inter-disciplinarity due failure to recognize two levels of inter-disciplinarity. Mono-disciplinary-oriented scientists frequently incorrectly consider inter-disciplinarity to be only an interdisciplinary approach inside a certain science. This misconception sees it as studying the subject of science from the point of view of more disciplines with the aim of training a researcher inside the discipline, who is able to produce new knowledge of his/her own discipline by applying knowledge from other disciplines. In real interdisciplinary research, the subject of the research does not belong to any distinct science, but encompasses complex problems that cannot be addressed by one discipline. The aim is to train an inter-disciplinarian who thinks across disciplines and produces research which goes beyond their borders. Other limitations, mentioned by Darbellay (2015, p. 167) include a lack of conceptual thinking in the area of interdisciplinarity, and conformity to a common practice. Interdisciplinary cooperation is often considered as something automatic when designing research projects involving scientists from various disciplines; it is not thought out or discussed.

The above-mentioned issues are also reflected in interdisciplinary studies. According to Jones (2010), due to the high popularity of interdisciplinary studies, in the effort to win students, interdisciplinary doctoral programmes frequently consist of various courses thoughtlessly piled up in a curriculum, sacrificing quality interdisciplinary strategies and methodology. If the course curriculum is reduced to "specialization" in a discipline, students have no synthesis of a broad range of disciplines. Jones also criticises the fact that when doctoral students are supervised by a team of supervisors from various disciplines responsibility is not always clearly defined (2010, p. 79).

As pointed out by Saari \& Moilanen (2012, p. 99), universities must strategically manage the development of inter-disciplinarity. They should purposefully stimu- 
late interdisciplinary research, form and develop interdisciplinary research communities, through the creation of strategic plans, integration of research themes, professionalization of interdisciplinary workplaces, networking, interdisciplinary studies and events. According to Saari \& Moilanen (ibid.) this requires good management by consensus of interdisciplinary research workplaces and teams, development of effective mutual understanding and communication of academic disciplines with each other as well as with interdisciplinary teams and institutions. In their view, a clear sign of maturity is synergy in the exploration of a theme from various perspectives, team collaboration, co-authorship and regular evaluation of the development of inter-disciplinarity.

Other authors, also emphasize the need for fruitful interaction between academic disciplines and interdisciplinary research. Mono-disciplinary institutions (academic disciplines, or departments) appear inevitable, as the integrity of monodisciplinary traditions is important for interdisciplinary research, because interdisciplinary research occurs only with reference to disciplines. They produce sources of knowledge and provide a common ground for communication with colleagues. They serve as reference points because research is also innovative in that it challenges the customary conventions of the discipline (Castán Broto et al., 2009).

A vibrant community of scholars, just like a thriving ecosystem, nurtures specialists and generalists, diversity and interconnections (Nisani, 1997, p. 213).

\section{Conclusion}

Despite the fact that the next period of science development will belong to inter/trans-disciplinarity, the answer to the question whether to lead doctoral students to careers as interdisciplinary scientists is complex. Interdisciplinary scientists encounter dilemmas and cultural barriers caused by an environment that is monodisciplinary, which leads them to career obstacles, and difficulties in qualification growth, or access to job positions that are organized by disciplines/ fields. Orientating towards interdisciplinary research may remove a doctoral student from the latest knowledge in his/her own discipline, interdisciplinary studies focus on "fringes" of a discipline, which lowers an academic's reputation in the eyes of his/her peers. Learning from other disciplines, and making reasonable connections between them, requires maturity and intellectual energy which threatens research in its initial phase. Interdisciplinarians - must overcome their colleagues' resistance to change. The greatest obstacle is the monodisciplinary 
oriented thinking of academics, who are suspicious of people that do not have a firm anchor in any discipline, and reject the idea of an interdisciplinary scientist who, in contrast to a specialist, has no complete mastery of his/her broad research field and risks "dilettantism to gain her bird's eye view" (Nisani, 1997, p. 212).

\section{References}

Bridle, H., Vrieling, A., Cardillo, M. Araya Y. \& Hinojosa, L. (2013). Preparing for an interdisciplinary future: A perspective from early-career researchers. Futures 53, 22-32.

Borrell-Damian, L., Morais R and Smith, J. H. (2015). Collaborative doctoral education in Europe: Research partnerships and employability for researchers: Report on DOC-CAREERS II Project. Brussels: EUA.

Carr, G., Loucks, D. P. \& Blöschl, B. (2018) Gaining insight into interdisciplinary research and education programmes: A framework for evaluation. Research Policy, 47(1), 35-48.

Castán Broto, V., Gislason, M. \& Ehlers, M. H. (2009). Practising interdisciplinarity in the interplay between disciplines: experiences of established researchers. Environmental science \& Policy, 12(7), 922-933.

Darbellay F. (2015). Rethinking inter- and transdisciplinarity: Undisciplined knowledge and the emergence of a new thought style. Futures 65, 163-174.

Duerr, L. L. (2008). Interdisciplinary Instruction. Educational Horizons, 86(3) 173-180.

Gibbons M., Limoges, C., Nowotny, H., Schwartzman, S., Scott, P. \& Trow, M. (1994). The new production of knowledge: the dynamics of science and research in contemporary societies. Thousand Oaks, CA, US: Sage Publications.

Graybill, J.K., Dooling, S., Shandas, V., Withey, J., Greve, A. \& Simon, G. L. (2006) A rough guide to interdisciplinarity: graduate student perspectives. Bioscience 56(9), 757-763.

Hasgall, A., Saenen, B. \& Borrell-Damian, L. et al. (2019). SURVEY Doctoral education in Europe today: approaches and institutional structures. Geneva: EUA-CDE.

Hicks, C. C., Fitzsimmons, C., Polunin, N. V. C. (2010) Interdisciplinarity in the environmental sciences: barriers and frontiers, Environmental Conservation 37(4) 464-477.

Huutoniemi K., Thompson Klein, J., Bruun, H. \& Hukkinen, J. (2010). Analyzing interdisciplinarity: Typology and indicators. Research Policy 39(1), 79-88.

Jones, C. (2010) Interdisciplinary Approach - Advantages, Disadvantages, and the Future Benefits of Interdisciplinary Studies. ESSAI, 7(1), 76-81.

Louw, J. \& Muller, J. (2014). A Literature Review of Models of the PhD. Retrieved from: https://www.idea-phd.net/images/docpdf/Louw_and_Muller_2014_Literature_ Review_on_Models_of_the_PhD.pdf

Mareš, J. (2013). Přehledové studie: jejich typologie, funkce a způsob vytváření. [Review Studies: their Typology, Function and Method of Creation]. Pedagogická orientace, 23(4), 427-454.

Matas, C. P. M. (2012). Doctoral Education and Skills Development: An International Perspective. Revista de Docencia Universitaria, 10(2), 163-191. 
Nissani, M. (1997). Ten cheers for interdisciplinarity: The case for interdisciplinary knowledge and research The Social Science Journal, 34(2), 201-216.

Saari, S. \& Moilanen, A. (eds.) (2012). International evaluation of Research and doctoral Training at the University of Helsinki 2005-2010. Helsinki: University of Helsinki, Administrative Publications 81.

Taylor, S., Kiley, M. \& Humphrey, R. (2018). A Handbook for Doctoral Supervisors. London, New York: Routledge World Economic Forum. (2016). The Future of Jobs, Employment, Skills and Workforce

Strategy for the Fourth Industrial Revolution. Available on: http://www3.weforum.org/docs/ WEF_Future_of_Jobs.pdf

World Economic Forum. (2018). The Future of Jobs Report. Available on: http://www3. weforum.org/docs/WEF_Future_of_Jobs_2018.pdf 